\title{
GLAMOROUS CONSUMPTION IN VIRTUAL REALITY
}

\section{Yana Semko ${ }^{1}$}

\section{DOI: https://doi.org/10.30525/978-9934-26-050-6-22}

To a person with a normal worldview, the word «virtual reality» refers to computers, which is not entirely accurate. This phenomenon entered our lives long before the advent of computers, and the term appeared at the turn of XIX-XX centuries. O. Otradnova defines virtual reality in two ways: as a form of object-social simulation that reproduces the conditions close to reality, through which it is possible to perform operations outside of objective reality, and as a fictional, ephemeral world, built according to the logic of objective reality. small changes in the social system [5, p. 49].

The first definition includes utopias or anti-utopias created by writers and sociologists, or dreams and fantasies that arise in human thoughts. The second is e-commerce, online shopping or social networking, which is directly related to computerization. However, a regular landline conversation, invented in the 19th century, also creates virtual reality, but only with sound. Theater, which appeared in antiquity, fine arts, the first examples of which were created in the ancient world, as well as photography and cinema, researchers also refer to virtual reality. From this we can conclude that computers have only supplemented and improved virtual reality, which appeared more than a century ago [6, p. 106-109].

Due to technical progress, virtual interactions are becoming more and more like real ones. Working at a computer becomes more like real events, and online communication is similar to communication in real space and time. Virtualization can be compared to the loss of the essence of things, but not in the sense of destroying the old, but in the sense of creating a new reality. This is evidenced by such characteristics of virtual reality as intangible influence, conditionality of parameters, ephemerality [7]. The concepts of the essence of a thing and an image are divided: a thing presupposes an essence that is revealed in its sensory image, in turn, we receive a sensory image with the help of the organs of hearing, sight, touch and smell. That is, the essence of a thing exists separately from its images, it is more than them in content, but at the same time, is expressed in them.

Today we can talk about the global process of virtualization of society. Sociologist D. V. Ivanov, who studied the process of virtualization, defined it as «a series of heterogeneous but similar trends in various spheres of life, such

\footnotetext{
${ }^{1}$ South Ukrainian National Pedagogical University named after K.D. Ushynsky, Ukraine
} 
as economics, culture, education, industry and even interpersonal relationships between individuals» [3, p. 65-66]. Simulation, as the main characteristic of virtual reality, is most pronounced, according to the researcher, in economics. Today the market is full of goods with similar technical characteristics, which need to compete with each other. This has led to the fact that the market is now selling not goods, but images, images, simulations, which determines the modern social organization. The simulation also applies to innovations attributed to goods: the «innovative brush» of mascara and the washable toilet paper sleeve is an attribution of the virtual value of the product. The consumer chooses not the product, but its virtual image, which entails a change in the pricing mechanism. Thus, virtualization creates a new concept of price.

Today, pricing is determined not by the principles of famous economic theories, but by Thomas Aquinas: the value of the offer determines its «origin», ie the brand name. In such conditions, it makes sense to talk about the decapitalization of business - today it is not the company that owns the capital that is successful, but the one that owns the brand. Levi's Signature, which Levi Strauss \& Co sells in Wal Mart supermarkets only in the United States, has been sewn since the fall of 2003 at the Russian Gloria-Jeans factory in the Rostov Region Mine. None of the company's existing factories in Hungary or Poland would be able to make jeans of acceptable quality at the record low price of \$ 25 needed to sell jeans in a supermarket and capture a cheap segment of the mass market. Today, consumers do not want to buy a quality thing, but to satisfy their emotional needs, solve internal problems, raise self-esteem. Firms successfully enjoy the emotional weakness and instability of consumers. Adidas sneakers designed by Yoji Yamamoto are successfully sold in boutiques at a price of $\$ 1,000$, although their cost is about \$ 100 [4, p. 4-8].

Therefore, advertising in modern society is not just information about goods, services or promotions. It, appealing to human feelings, gives an imitation of missing emotions, influencing feelings of fear, sense of selfimportance, belonging to a social group, etc., ie mobilizes affective connotations by creating an advertising image.

In cultural conditions, postmodern brand creation is a way of symbolic manipulation, the purpose of which is to form a stable human reaction to certain symbols. The status of these symbols (trademark) determines the value of the thing, and a direct connection with its real properties is often not observed. Zh. Bodriyyar noted that in the postmodern state, the signs that served reality are now usurping it. The meaning of a sign is not a thing, but another sign. When reality is reduced to a whirlwind of signs, it becomes hyperreality [1]. As you can see, in addition to the advertising process, this statement perfectly expresses its essence. 
Today, any benefits have already been done and the market faces the task of stimulating unlimited consumption. To produce more goods at the lowest possible cost and short service life - this is the task of production. This reinforces the endless demand for things. The consumer will have to buy a novelty not only because last season's product went out of fashion, but because consumer properties have already deteriorated. "Competitive tuning» has become a typical expression for any business. Today, the product is unthinkable without a brand. Its first function is to denote a commodity, the second is to mobilize affective connotations.

For the consumer, this phenomenon dictates the need to choose not from tangible goods, but from images that include the virtual benefits of tangible goods. Hence the high advertising susceptibility - the consumer is full and dressed, but his needs do not stop, because he must meet the images of success, health and so on.

Interactions with the product in the virtual Internet environment become available to the consumer. Without taking any action in reality, but only by dragging the mouse on the table or finger on the touch screen, a person is able to conduct financial transactions, make purchases.

Technical improvement of computers, which were once called computers, does not lead to qualitatively new methods of information processing, but improves visualization technologies. Virtual Reality Modeling Language (VRML) has been used on the Internet for several years. It is recognized by the Web Consortium as the standard (ISO / IEC 14772) for describing interactive 3D graphics and multimedia applications. This is an independent object-oriented extensible programming language, which in the most general principles resembles the well-known to web-page designers HTML language. However, it differs from the latter in its ability to represent objects and their environment in motion and three-dimensionally. VRML is an alternative, not a complement to HTML. This means that in the case of widespread VRML, the World Wide Web system will become as if two layers: pages in HTML will be adjacent to pages in VRML, referring to each other.

If HTML has brought the Internet closer to people and made the network more accessible, then VRML takes the Internet and the World Wide Web to the next level, making them accessible to billions of people who would rather watch TV instead of rearranging «windows» in computer applications [2].

The development of 3D and 2D visualization technologies has opened up new opportunities for e-commerce. We can assume that a new branch of computer science has now been formed - three-dimensional, or 3D-machine graphics. With the help of three-dimensional interactive models on a personal computer, you can create a simulation of the real world. 
Ukrainians are no longer afraid to buy even furniture online. They design their interior online, then order the appropriate product at home with the click of a button. According to research, every tenth resident has already bought furniture online. Ukrainians have been shopping online since 2008, after three years of active Internet use. Since the onset of the crisis, traditional retail sales have fallen by $5,5 \%$, while e-commerce has grown by $20 \%$. It began to develop first in Kiev, Lviv, Odessa and the Dnieper, due to the high speed of the Internet, and today has spread throughout Ukraine.

Consumers are attracted by the lack of queues, a large selection of goods that can be ordered in both Ukrainian and foreign stores. Shopping in online stores saves time - the goods can be delivered directly home. Online shopping saves money. In the last few years, cashback services (cash back) have become popular in online stores. They are used by both banks and special sites. This allows the consumer to save from $1 \%$ to $5 \%$ on their purchases.

Thus, virtual reality has formed a new type of consumer behavior. Consumers do not buy goods, but images created by companies, the life cycle of goods is reduced, and the development of visualization technologies allows you to choose goods online with greater convenience than offline.

\section{References:}

1. Bodriyyar Zh. (2006) Obshchestvo potrebleniya. Yego mify i struktury [Consumer Society. His Myths and Structures]. Moscow: Respublika. (in Russian)

2. Buyanov A. S. (2011) Sredstva sozdaniya virtualnykh realnostey [Means of creating virtual realities]. Successes of modern natural science, no. 7, pp. 85-86.

3. Ivanov D. V. (2000) Virtualizatsiya obshchestva [Virtualization of Society]. Peterburg: Peterburgskoye Vostokovedeniye. (in Russian)

4. Malkova Ye. V. (2011) Sovremennyy fenomen virtualizatsii stoimosti [The modern phenomenon of value virtualization]. Bulletin of Perm University. Philosophy. Psychology. Sociology, no. 1, pp. 4-8.

5. Otradnova O. A. (2012) Virtualnaya realnost kak fenomen sovremennogo obshchestva [Virtual reality as a phenomenon of modern society]. Topical issues of social sciences: sociology, political science, philosophy, history, Novosibirsk, pp. 48-52.

6. Sibin M. S. (2009) Reklama kak produtsent virtualnoy realnosti [Advertising as a producer of virtual reality]. Omsk Scientific Bulletin, no. 3(78), pp. 106-109.

7. Suvorov K. A. (2013) Sistemy virtualnoy realnosti i ikh primeneniye [Virtual reality systems and their application]. T-Comm, no. 9, pp. 140-143. 